\title{
Media and Massacre: A Comparative Analysis of the Reporting of the 2007 Virginia Tech Shootings
}

\author{
Jaclyn Schildkraut
}

\section{Introduction}

On April 16, 2007, Seung-Hui Cho launched what would eventually result in the largest mass casualty school shooting to date.[1] He first murdered two students in the West Ambler Johnston dormitory on Virginia Tech's campus. After a two-hour break, during which time he sent a detailed manifesto to NBC chronicling his hatred for society and prepared for what he viewed as a battle, Cho entered Norris Hall and opened fire. In his wake, he left an additional 30 students and faculty members dead. Over the course of the day, millions of people turned to media outlets as their sources of information. Fox News reported 1.8 million viewers tuned in to watch the breaking story unfold, while CNN reported 1.4 million viewers (Garofoli 2007). MSNBC.com also reported 108.8 million page views on their website (Garofoli 2007).

Though school shootings have appeared in historical references since as early as 1913, it was not until the late 1990s that these events became viewed as epidemic across the United States (Muschert 2007a). Shootings at schools in Jonesboro, AR (Westside Middle School), Pearl, MS (Pearl High School), Springfield, OR (Thurston High School), and perhaps most infamously, Littleton, CO (Columbine High School) were thrust into the nation's consciousness through the media. As few people will ever experience a school shooting first hand (Muschert 2007a), their collective understanding about the phenomenon is derived mainly from the media (Birkland and Lawrence 2009; Chermak 1995; Muschert 2007a). Information is disseminated across a variety of reporting styles, which in turn is received and processed differently among news consumers. This effect, often referred to as mediatization, refers to society's dependency on the media in constructing their understanding of "reality" (Hjarvard 2008). The increased attention on media events leads to them taking on a life of their own, and essentially what is presented in the media becomes "more 'real' than the real-life events" (G. Muschert personal communication, June 15, 2011).

The framing of a school shooting in the media also contributes to mediatization. The present study examines the 2007 Virginia Tech Massacre for a one-month period following the event in two nationally recognized newspapers - The New York Times and The New York Post. The Times is considered to be more "hard news," while The Post is stylistically more "infotainment". It would be expected that these different reporting styles would yield different mediatization outcomes for the shooting. This study seeks to examine differences in news content between these two papers, and then discusses how these different approaches may have contributed to the mediatization of the Virginia Tech Massacre and school shootings as a phenomenon.

\section{Review of Literature}

School shootings typically have been a difficult phenomenon to define. One commonly accepted definition 
is that school shootings are those that "take place on a school-related public stage before an audience; involve multiple victims, some of whom are shot simply for their symbolic significance or at random; and involve one or more shooters who are students or former students of the school" (Newman, Fox, Harding, Mehta, and Roth 2004: 50). Though such incidents as Columbine and Virginia Tech suggest that school shootings are a cause for national concern, it is actually the media coverage of these rare events that concentrates attention on them, which are not indicative of actual levels of school violence (Muschert 2007a).

\section{Newsmaking and Violence in the Media}

Crime news plays a prevalent role in today's society (Cerulo 1998; Schildkraut and Donley 2012), and in some instances, the mass media can serve the function as the primary source of information for up to $95 \%$ of the general population (Graber 1980; Surette 1992). This drastic dependence on the mass media emerges through the lens of fast capitalism, a term coined by Ben Agger (1989) to describe the transition to an economic model that exists "by objectifying and commodifying all human experience" (p. 6). In an era filled with up to the minute news and reality television, one need to do little more than press a button to capture the human experience from the comfort of their own living room. This represents a shift to a more "infotainment society" (Kellner 2003: 11), a shift that has also impacted the way in which social audiences view violence (Cerulo 1998).

Crime news is essentially a product that news producers want to sell to their audience (Buckler and Travis 2005; Chermak 1995; Johnstone, Michener, and Hawkins 1994; Pritchard and Hughes 1997) and more viewers equals more money. As a result, the media tends to disproportionately report on violent crimes (Schildkraut and Donley 2012, Surette 1992), and as Surette (1992: 246) notes, "presents a world of crime and justice not found in reality." Violence in the media can be divided into three types - deviant violence (acts that are heinous and unacceptable), normal violence (acts which may be considered justifiable or acceptable), and ambiguous violence (which cannot be classified) - and which category a story falls in will impact its formatting and its prevalence (Cerulo 1998: 6).

While the process of mediated communication may seem somewhat of a simple and direct process - the media gets the story, the media airs the story, and viewers consume the story - the reality is that the process of mediatization is far more fluid. For instance, with such an abundance of crime news to choose from and never enough time to air it all, media conglomerates must rely on public interest to determine what gets aired and what gets left on the cutting room floor (Chermak 1995; Gans 1979; Maguire, Sandage, \& Weatherby 1999; Surette 1992). Once the decision of what to air is made and the story hits the airwaves, the focus becomes ensuring that the audience's attention is both captured and kept (Cerulo 1998). If audiences latch on to a story and the media has what is considered "ratings gold" (as with the cases of both Columbine and Virginia Tech), they will communicate this approval back to the media who will in turn continue to turn out stories in an effort to keep their viewers hooked. If the audience conveys a dissatisfaction or disinterest in the story, the networks will either rework or replace with a different story. This process involves a continual "dialogue" or ongoing communication between the senders and receivers of mediated messages (Cerulo 1998; Chiricos, Padgett, and Gertz 2000; Luke 1989).

Though a fluid (or as Cerulo (1998) notes, dynamic) process, the mediatization of a news story still relies on three important and distinct components - the production of the content, the content itself, and the consumption of the content. The production phase involves journalists and editors deciding what stories are presented and which are not (Chermak 1995; Gans 1979; Liska \& Baccaglini 1990; Lundman 2003; Meyers 1997). Newsworthiness, which Surette (1992: 60) defines as "the criteria by which news producers choose which of all known events are to be presented to the public as news events," is based on a number of factors including (but not limited to) the target audience and journalistic style of the news producer (Schildkraut and Donley 2012) as well as how news makers perceive their consumers' opinions and values (Cerulo 1998; Gans 1979). Additional factors contributing to newsworthiness include the characteristics of both the victim(s) and offender(s), the nature of the act, and the context in which the act occurs (Cerulo 1998). Ultimately, the need to produce news efficiently and with a quick turnaround affects the manner in which such newsworthiness is assigned (Chermak 1995; Gans 1979).

Research on media consumption is as vast as the disciplines through which it extends. In examining the relationship between crime news and media consumption, however, the focus is more defined. After all, the majority of the public's perceptions and understanding about crime, criminals, and the criminal justice system are derived from the media (Dowler 2003; Pollak and Kubrin 2007; Surette 1992). One important consideration that has been the focus of much research (see for example Chiricos et al. 2000; Dowler 2003; Heath 1984; Liska and Baccaglini 1990 ) is whether fear among news consumers is an outcome for violent, sensationalized news stories. Chiricos et al. 
(2000), Heath (1984), and Liska and Baccaglini (1990) for instance all found that an abundance of non-local crime news can make residents of a particular locale feel safer, yet even so, homicide stories are the strongest predictors of fear among consumers. Gerbner and colleagues (1980) found the patterns of consumption also impact consumers' fear of crime - the greater the amount of television consumption, the higher the level of fear.

The content itself is essentially a by-product of the production and consumption of news and how the news is consumed is also important, as the manner in which the content is reported can have varying effects on consumers' perceptions of crime. For instance, Hjarvard (2008) posits many of people's social interactions take place via the media. The continual reinvention of social media, with the introduction of such sites as Facebook and Twitter, also helps to fuel media consumption (Schildkraut forthcoming). For instance, when news of a school shooting breaks, these websites become a lifeline of sorts for victims reaching out to assure others they are okay, as well as family members searching for loved ones. Couldry (2008) also posits that the use of such sites has become a vehicle for "digital storytelling" that helps to immortalize the events (p. 381). Other forms of social media, including weblogs, personal and memorial websites with photos and message boards, and even personal videos captured by cell phone and posted on YouTube also can serve as archives (Couldry 2008). The content of the story that is ultimately presented to news consumers is further influenced by the manner in which the story is framed, which is the discussion that follows in the next section.

\section{Media Framing}

The mediatization of school shootings is largely influenced by the way news stories are framed. Similar to mediatization, much of the literature on media framing revolves around the political agendas that are presented to society. Though the concept of framing, first introduced by Goffman (1974), was introduced to explain how members of society make sense of the world around them, it also has been refined as an explanation for the impact of the media. In a broader sense, media framing has become a way for presenting complex social issues to make them accessible and relatable to the intended audiences (Gans 1979; Scheufele and Tewksbury 2007).

A media frame has been defined in the literature as "a central organizing idea for news content that supplies context and suggests what the issue is through the use of selection emphasis, exclusion, and elaboration" (Tankard 2001: 100-101). Reese (2007) suggests that media frames may surface as certain aspects of a particular news story and its "reality" are emphasized. Entman (1993) also proposes that "to frame is to select some aspects of a perceived reality and make them more salient in communicating text, in such a way as to promote a particular problem definition, causal interpretation, moral evaluation, and/or treatment recommendation" (p. 52). From this idea has stemmed the notion of content bias, which has been described as patterns in framing that result from the influence of social institutions, media routines, or media hegemony (Reese 2007; Shoemaker and Reese 1996).

Scheufele (1999) posits that framing is not restricted to either a macro-level or micro-level construct but rather can address issues across both. This movement between levels allows the media to change the presentation of information over a continuum. Muschert and Carr (2006) also explain that the media can influence perceived public reality by changing the frames of the news coverage during an event. The change in frames helps to highlight different features of a particular news story that the media select as important (Altheide 2009; Chyi and McCombs 2004; Muschert 2007b). This enables the media outlet to keep the audience hooked by providing fresh content (Altheide 2009).

Cerulo (1998) builds on Luke's (1989) discussion of media fluidity in examining the framing process. She suggests that violence in the media is presented through one of four distinct sequences of narration - the victim sequence, the performer sequence, the contextual sequence and the doublecasting sequence (p. 5). Both the victim and performer sequences highlight the perspectives of the respective social actors. In particular, Cerulo (1998) notes that newsworthiness can be influenced by framing stories around out-group or minority perpetrators who do not fit the common social profile, or those victims who are perceived as "unlucky bystanders caught in the wrong place at the wrong time" (p. 26). She also notes that framing particular acts based on their nature (especially those using excessive force) and the context of the act can impact how the audience receives and perceives the act (Cerulo 1998).

\section{Columbine High School in the Media Framework}

To date, there has been very little systematic (rather than conceptual) research on the Virginia Tech Massacre. 
However, there is a considerable amount of research on the Columbine High School shooting, as this is typically the benchmark case to which all other school shootings are compared (Altheide 2009; Muschert and Larkin 2007). On April 20, 1999, students Eric Harris and Dylan Klebold launched an attack on their high school, leaving 12 students and one teacher dead (United States Federal Bureau of Investigation 2003)[2]. The changes in framing of Columbine over the hours and days as the story unfolded yielded many different contexts in which to try to understand why this event happened and what had taken place.

Initially, as the story broke, news of the events was confined to the community (Chyi \& McCombs 2004). By the end of the day, however, the news had spread across the country and the world (Chyi and McCombs 2004; Muschert, 2009). The initial focus of the reporting was on community and police reactions (Muschert 2009). As the reporting progressed, reactions came from those who were not directly involved with the school, the shooting or the Littleton community (Muschert 2009). Discussion went from safety in Littleton to safety in all suburban area high schools and new agendas including the gun control debate took center stage (Altheide 2009).

In addition to speculation about all students' safety, the way in which the media framed Columbine opened discussion about Harris and Klebold, as well as their victims. Most importantly, everyone sought to answer the allelusive question of why. The media tried to fit this event into many different frames (Altheide 2009; Frymer 2009; Muschert, 2007a,b; Muschert and Ragnedda 2010). In several instances, they framed the shooting as an instance of domestic terrorism and compared it to the Oklahoma City bombing (Altheide 2009). In later years, the media would again try to link Columbine with terrorism by suggesting similarities between Columbine and $9 / 11$, as well as between Klebold and Harris and Al-Qaeda (Altheide 2009). The killers would be portrayed as "alienated youth gone horribly wrong” (Frymer 2009: 1387). Victims, including Isaiah Shoels, Cassie Bernall and Rachel Scott, would be framed as both martyrs and specific targets of the killers - Shoels because of his race and Bernall and Scott for their religious beliefs (Muschert 2007b). In sum, Columbine became a problem-defining event that is still recognized as such years later (Muschert 2007a).

\section{The Present Study}

There has been considerable speculation about the social impact of the Virginia Tech shooting. The Pew Research Center for the People and the Press (2007) found Virginia Tech to be the leading news story of the week of occurrence, accounting for more than half of the news coverage presented. Other stories that were followed that week included the war in Iraq, a critical ruling on abortion legislation and the 2008 presidential campaign (Pew Research Center for the People and the Press 2007). Network news stations devoted over 60\% of coverage to the shooting, while the cable news networks allocated $76 \%$ of their coverage to the shooting (Pew Research Center for the People and the Press 2007). However, in relation to Columbine, Virginia Tech was the fifth most closely followed school shooting behind Columbine, Jonesboro, Springfield, and the Amish Schoolhouse massacre with public interest around 45\% of polled Americans (Pew Research Center for the People and the Press 2007).

Though examining the full process of media decisions is important, examining each component (the production, the consumption and the content itself) independently can also be beneficial in gaining insight into the process as a whole. The present study takes the first step by examining the content of media relating to the Virginia Tech Massacre. By utilizing mediatization effects and the framing by the media, the victims, the perpetrator and the events as a whole are examined to gain insight into how the media create our impressions of school shootings through reporting styles. To date, while research has been conducted with relation to media framing and television news, virtually no study has examined the construction of the shooting incident and the people involved (perpetrator, victims and community) within the print medium (newspapers and magazines). This study seeks to fill this gap within the literature by examining the evolution of the story of the Virginia Tech Massacre within the newspaper medium over a one-month period following the initial date of the shooting. I also discuss how these results may influence both the production and consumption phases.

\section{| Methodology}

Data

All articles pertaining to the Virginia Tech shooting were collected from two newspapers, The New York Times 
and The New York Post. The Times was selected for its "hard news" approach and because it is often viewed as a national standard for printed news coverage (Altheide 2009; Muschert 2002). In many instances, The Times acts as a source of news for other publications that may reprint their articles (Muschert 2002). Conversely, The Post was selected for its tendency to report stories in a more "infotainment" style. Though "infotainment" news will report crime in a factual manner, there is the tendency to sensationalize the facts in order to capture a broader reader audience (Altheide 2009; Surette 1992). Beyond their stylistic differences that support the main research question in this study, The Times and The Post were selected because they are both nationally distributed newspapers from the same region. Additionally, both papers have readership totals in excess of 500,000[3], as well as an equally strong online presence[4].

A search was conducted through each newspaper's online archive using the searchable term "Virginia Tech." In total, 181 articles were found in The Times and 76 articles were found in The Post. From there, articles pertaining to sporting events or opinion and editorial articles were discarded from the dataset. Opinion and editorial articles were excluded as the focus of the present study is on stories that are considered actual news accounts. This left a final dataset of 63 articles from The Times and 50 articles from The Post.

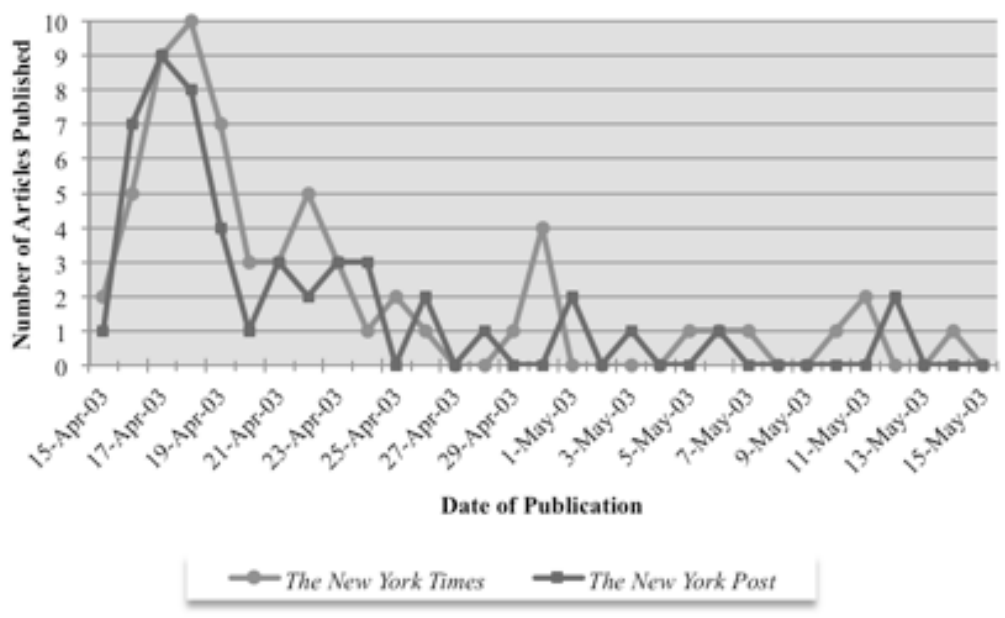

Figure 1. Distribution of Articles By Paper and Publication Date

The present study covers the period between April 16, 2007 (the day of the shooting) and May 16, 2007. Researchers have previously utilized the one-month period in examining other events, such as The Columbine High School Massacre (e.g., Chyi and McCombs 2004 or Muschert 2007b). McCombs and Zhu (1995) have previously noted that coverage on public issues typically lasts an average of 18.5 months. However, Chyi and McCombs (2004) found the life span of the Columbine Massacre to be only about month (p. 23). The limited span of coverage for school shootings could be due to Downs' (1972) notion of the "issue-attention cycle," whereby interest in intense issues gradually fades and these focal points are replaced by the media and the public by another intense issue.

\section{Coding}

A qualitative mixed analytic approach with open coding, graduating upwards to axial coding, is utilized to find underlying themes within the articles. Strauss and Corbin (1998) define open coding as "the analytic process through which concepts are identified and their properties and dimensions are discovered in data" (p. 101). This process allows for identification of specific words in each statement that are made within the context of each article. Altheide (1996) also notes that the repetition of certain words or phrases can add emphasis to the symbolic meaning of the story, regardless of whether the article is factual. These words are used to begin conceptualizing categories that eventually lead to themes in the articles. For this particular study, key words and phrases, such as the names of the shooter and the victims, descriptors or adjectives identifying either, and descriptors of the shooting as an event, were coded during this phase. The following is a sample of the open coding technique utilized, as illustrated with an 
article published in the New York Post (Sheehy 2007):

\begin{abstract}
A baby-faced madman in a "Boy Scout-type outfit" yesterday strolled onto the bucolic campus of Virginia Tech University and turned it into hell on Earth - killing 30 students and two teachers before blowing his brains out in the worst shooting massacre in U.S. history.
\end{abstract}

As terrified victims screamed, "Oh, my God!" flipping over their desks to dodge flying bullets and smashing windows to leap from second-floor classrooms, the gunman methodically walked through the halls of a building at the prestigious engineering school and coldly fired into classrooms.

\begin{tabular}{|l|l|}
\hline \multicolumn{2}{|c|}{ CODING LEGEND } \\
\hline Shooter's Sense of Innocence / Youth & Shooter As The Feared \\
\hline Shooter Behavior: Anger / Enraged & Shooter Behavior: Calculated / Planned \\
\hline Shooting As An Infamous Event & Victim Behaviors and Reactions \\
\hline
\end{tabular}

After analyzing each article line by line using open coding, axial coding is used to delve deeper into the investigation with a higher level of abstract conceptualization. Axial coding, while a complex method, could be summed up simply as assembling concepts into categories, which developed out of the data itself. Strauss and Corbin (1998) note, "The purpose of axial coding is to begin the process of reassembling data that were fractured during open coding. In axial coding, categories are related to subcategories for more precise and complete explanations about phenomena" (p. 124, italics in original). The phenomena are references for the issue or controversy being researched, and the categories provide a link relating the ideas or concepts found in open coding through comparable characteristics. It is important to note that in this study, the coding and categorizing of terms was discrete, meaning that the key words or phrases could only belong to a single category (Muschert 2002). The articles are then further analyzed for the frequency of terms or concepts within the articles, and then summarized to suggest themes or ideas that were more prevalent or heavily saturated within the datasets.

\title{
Analysis and Findings
}

Reports about school shootings are composed of many elements, including the perpetrator, the victims and the event itself (Chermak 1995). The way a story is framed may be based upon all of these elements together, individually, or in some alternate combination (Chermak 1995). As such, in order to determine the full impact of the Virginia Tech shooting, this analysis examines each of the three elements' individual constructs in respect to the way the news stories were framed. The concluding section discusses the convergence of these elements and how they impact the overall mediatization of the event. Noteworthy words within each passage are emphasized in italics (Spencer 2005).

\section{Virginia Tech: The Event}

The expressions used to describe the tragic event itself are as varied as those describing the killer and the victims. The Virginia Tech shooting surpassed the 1991 Luby's Cafeteria massacre[5] in death toll and remains the largest mass shooting (by casualties) to date in U.S. history.

Table 1. Classification of the Event As Extracted From the Articles

\begin{tabular}{|l|l|l|l|l|}
\hline Terminology Used To Define the Shooting & The New York Post & \multicolumn{2}{l|}{ The New York Times } \\
\hline & References & Percentage & References & Percentage \\
\hline Worst Mass Shooting in U.S. History & 5 & 6.49 & 22 & 25.29 \\
\hline Bloodbath / Bloodshed & 7 & 9.09 & 1 & 1.15 \\
\hline Rampage & 25 & 32.47 & 41 & 47.13 \\
\hline
\end{tabular}




\begin{tabular}{|l|l|l|l|l|}
\hline Killing Spree & 7 & 9.09 & 2 & 2.29 \\
\hline Massacre & 33 & 42.86 & 21 & 24.14 \\
\hline \multicolumn{6}{|l|}{} \\
\hline TOTALS & $\mathbf{7 7}$ & $\mathbf{1 0 0 . 0 0}$ & $\mathbf{8 7}$ & $\mathbf{1 0 0 . 0 0}$ \\
\hline
\end{tabular}

The high death toll and enormous tragedy of the event is a theme that is echoed article after article in each of the newspapers. In particular, it is characteristically the headlines where this theme is most visible, as this is typically the author's first chance to hook readers. A typical headline, particularly on the day following the event, was:

Massacre in Virginia; 32 Shot Dead in Virginia; Worst U.S. Gun Rampage (Broder 2007)

College fiend guns down 32: Nightmare at Virginia Tech is worst shooting slaughter in U.S. history (Sheehy 2007)

Table 2. Article References to Other Mass Shooting Events

\begin{tabular}{|l|l|l|l|l|}
\hline Terminology Used To Define the Shooting & The New York Post & \multicolumn{2}{l|}{ The New York Times } \\
\hline & References & Percentage & References & Percentage \\
\hline Columbine High School Massacre & 5 & 83.00 & 16 & 64.00 \\
\hline University of Texas Shooting & 0 & 0.00 & 5 & 20.00 \\
\hline Amish Schoolhouse Shooting & 1 & 17.00 & 4 & 16.00 \\
\hline Luby's Cafeteria Massacre & 0 & 0.00 & 2 & 8.00 \\
\hline Dunblane School Shooting & 0 & 0.00 & 3 & 12.00 \\
\hline & \multicolumn{5}{|l|}{} \\
\hline TOTALS & $\mathbf{6}$ & $\mathbf{1 0 0 . 0 0}$ & $\mathbf{2 5}$ & $\mathbf{1 0 0 . 0 0}$ \\
\hline
\end{tabular}

Writers at both The Post and The Times also utilized previous mass shooting incidents, predominantly Columbine, as a point of comparison for their readers. A number of the articles referenced these events in their discussions of gun control. After the 1999 Columbine High School shooting, gun control legislation had become a primary topic of debate, particularly with regards to stricter controls on the ability to purchase the weapons (Bishop 2007). The ease by which Cho could purchase his weapons, despite a clearly documented history of mental illness, reignited this debate. Further contributing to the referencing of other events came from Cho himself, who in his manifesto sent to NBC News, branded Columbine killers Eric Harris and Dylan Klebold as martyrs (Kleinfield 2007).

\section{Reporting of the Shooter}

It could be argued that there is no more iconic figure from the Virginia Tech Massacre than the shooter, SeungHui Cho. The April 18, 2007 release of his multimedia manifesto by NBC News caused public interest to soar, calling for the media to turn out more stories on the shooting. In examining newspaper coverage following the event, a number of themes emerged within the context of coverage of the shooter. Each emerging theme provided a new frame in which to understand this tragedy.

Table 3. Conceptual Themes About the Shooter Extracted From the Articles

\begin{tabular}{|l|l|l|l|l|}
\hline Themes & \multicolumn{2}{|l|}{ The New York Post } & \multicolumn{2}{l|}{ The New York Times } \\
\hline & References & Percentage & References & Percentage \\
\hline Shooter As The Feared & 77 & 32.63 & 73 & 41.24 \\
\hline
\end{tabular}




\begin{tabular}{|l|l|l|l|l|}
\hline Youth / Innocence & 27 & 11.44 & 15 & 8.48 \\
\hline Anger / Enraged & 28 & 11.86 & 36 & 20.34 \\
\hline Calculated / Planned / Cold & 32 & 13.56 & 20 & 11.30 \\
\hline Mental Health / Illness References & 72 & 30.51 & 33 & 18.64 \\
\hline \multicolumn{7}{|l|}{} \\
\hline TOTALS & $\mathbf{2 3 6}$ & $\mathbf{1 0 0 . 0 0}$ & $\mathbf{1 7 7}$ & $\mathbf{1 0 0 . 0 0}$ \\
\hline
\end{tabular}

Arguably, the most prevalent theme to appear in the news coverage is that of the shooter as someone to be feared. In many instances, this was accomplished simply by labeling Cho as a "gunman," "murderer," or "killer." However, other articles, particularly in The Post, took this theme to a more glorified level, such as in this account:

Thirty-two students and teachers were killed in Virginia a week ago by a maniacal classmate. (Celona, Sheehy, and Sullivan 2007)

Following the idea of the shooter as someone to be feared, the next most prevalent theme pertained to Cho's mental illness, which would become a front-stage topic as coverage progressed. Investigation into the shooting would uncover that Cho had a history of psychological problems, even so far as being declared an imminent danger to himself and others and ordered to receive treatment (Virginia Tech Review Panel [VTRP], 2007). Cho's mental health was the second and third most referenced category in The Post and The Times, respectively, in such excerpts as these:

One English professor was so freaked out by the shocking, murderous themes of Cho's "plays" that she called the campus police - and anyone who'd listen - to report that he could be a homicidal maniac. (Peyser, de Kretser, and Li 2007)

The chilling images and rantings of the insane gunman silenced crowds near the stricken campus as they played on television. (Winter, Li, and Gittens 2007)

It's obviously much easier to realize that someone is dangerously deranged after he has killed 32 people than when dealing with uncertain knowledge in an environment where any wrong (or even correct) move means a lawsuit. (Lowry 2007)

Campus authorities were aware 17 months ago of the troubled mental state of the student who shot and killed 32 people at Virginia Tech on Monday, an imbalance graphically on display in vengeful videos and a manifesto he mailed to NBC News in the time between the two sets of shootings. (Dewan and Santora 2007)

Perhaps the most interesting frame in which Cho appears double casts him as a "victim and a victimizer" (Spencer 2005: 55; see also Cerulo 1998). A frame such as this also identifies the shooter as a member of either the in-group or out-group (Cerulo 1998). These characteristics, coupled with the shooter's psychological sketch, can also help to guide the audience's interpretation of the shooter's actions. Further, this frame plays seemingly on the juxtaposition of hardened criminal and youthful innocence, such as in these accounts:

A baby-faced madman in a "Boy Scout-type outfit" yesterday strolled onto the bucolic campus of Virginia Tech University and turned it into hell on Earth - killing 30 students and two teachers before blowing his brains out in the worst shooting massacre in U.S. history. (Sheehy 2007)

In two photos, he looks like a typical smiling college student. In 11, he aims one or two handguns at the camera, posing as if in an action movie. (Dewan and Santora 2007)

Any attempt to romanticize madness has an incontrovertible answer in Cho Seung-Hui. This is what madness truly is: lonely, painful, shattering and, potentially, murderous. After seeing the sick trail of misery left by such transgression, can we expend some of the same intellectual energy honoring wholesome normality? (Lowry 2007)

In total, over 400 individual references were made about Cho across 113 articles through several overarching themes. These varying themes about the shooter only helped to fuel people's interest in the event. By portraying Cho through the different lenses, readers were given a killer that could be feared even in death, a notion fueled by the release of Cho's personal manifesto. Though discourse on his mental health status could provide some context for the massacre, it also served to heighten potential social panic about the shooting. 


\section{Reporting of the Victims}

Previous research (e.g., Chermak 1995 or Muschert 2007b) also has focused on the manner in which victims are framed in media accounts. Chermak (1995), for instance, posits that victims and their stories are often the most dramatic facet of news accounts and garner a significant amount of the media focus. Muschert (2007b) tested this notion in his examination of the media coverage of the Columbine High School victims. He found varying amounts of coverage for each of the victims as well as several narrative themes that were applied to the victims' coverage (Muschert 2007b).

Unlike the shooting at Columbine where all of the victims were killed in a single incident, the Virginia Tech victims were killed in two separate incidents, though the shooting is largely classified as one event. The first shooting occurred in the West Ambler Johnston Hall dormitory early in the morning, where Cho shot and killed freshmen Emily Hilscher and senior Ryan Clark (VTRP 2007). Hilscher and Clark were the two most prominently featured victims of the Virginia Tech massacre. Hilscher, the most published victim, was suspected at one point to be directly linked to Cho, though this was later dispelled.

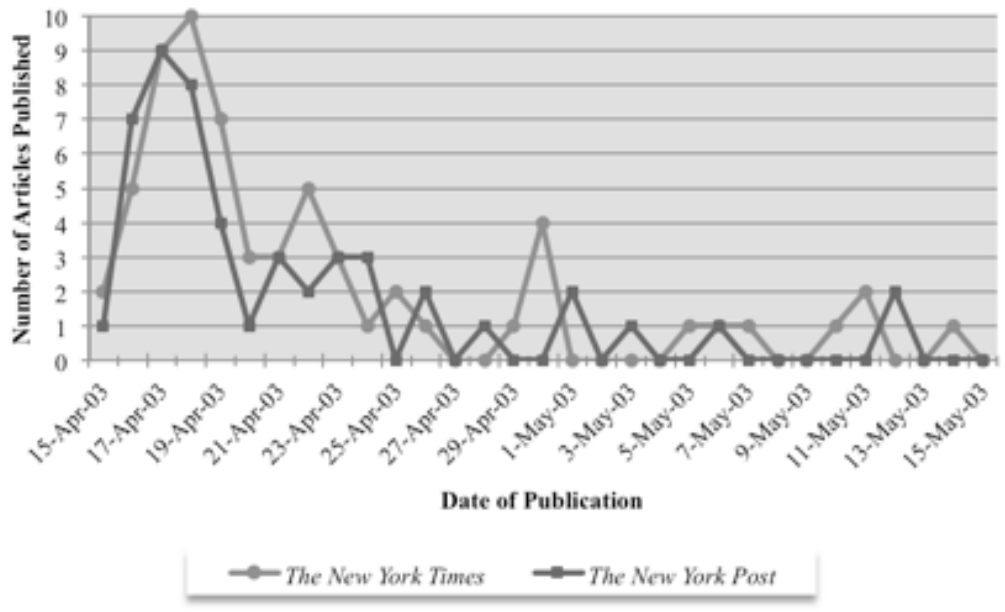

Figure 2. Number of References By Victim

The remaining 30 victims were shot and killed nearly two-and-a-half hours later in Norris Hall on the other side of the campus (VTRP 2007). Of these, professor Liviu Librescu was the most covered victim from this site in both The Post and The Times. Librescu, a Holocaust survivor, died as he blocked the classroom door with his body, sparing his students' lives as they escaped through the window (Belluck 2007). The remaining four professors - Kevin Granata, Jocelyn Couture-Nowak, Jamie Bishop, and G.V. Loganathan - all received similar amounts of coverage (two to four mentions) in The Times, but only Bishop, a German professor, received any coverage in The Post. While all of the students killed in the massacre received at least one mention in The Times, 18 of the 25 students received no coverage in The Post. Of the remaining seven students, six received mention in one article, and one student - Julia Pryde - received mention in two. In The Times, freshman Rhima Samaha was the most covered victim with five mentions. Samaha had an interest in dancing, but had also attended the same high school as SeungHui Cho (Urbina and Lee 2007).

Table 4. Themes About the Victims Extracted From the Articles

\begin{tabular}{|l|l|l|l|l|}
\hline Themes & \multicolumn{2}{l|}{ The New York Post } & \multicolumn{2}{l|}{ The New York Times } \\
\hline & References & Percentage & References & Percentage \\
\hline Heroism & 5 & 20.83 & 4 & 7.55 \\
\hline Drive / Determination & 5 & 20.83 & 5 & 9.43 \\
\hline Energy / Skill / Zest for Life & 2 & 8.34 & 9 & 16.98 \\
\hline
\end{tabular}




\begin{tabular}{|l|l|l|l|l|}
\hline Academic / Job Accomplishment & 6 & 25.00 & 9 & 16.98 \\
\hline Personality / Moral Character & 6 & 25.00 & 26 & 49.06 \\
\hline \multicolumn{6}{|l|}{} \\
\hline TOTALS & $\mathbf{2 4}$ & $\mathbf{1 0 0 . 0 0}$ & $\mathbf{5 3}$ & $\mathbf{1 0 0 . 0 0}$ \\
\hline
\end{tabular}

The majority of the discourse on the victims focused on celebrating their lives and their accomplishments. References to their personality traits were the most prevalent theme discussed. Both papers touched upon the victims' amiable natures, willingness to help and personal spirit. Academic or job accomplishments also were discussed. Of the students that were killed during the massacre, Jarrett Lane was valedictorian of his high school (Urbina and Fernandez 2007), and Henry Lee was salutatorian of his high school (Belluck, 2007). Professor Kevin Granata was considered a leader in his field (Belluck 2007), and all professors were each highly accomplished in their own right. While there were many heroes on the day of the shooting, one emerged in nearly all references - Liviu Librescu. Accounts within the articles trumpeted Librescu's final act:

About 300 people showed up at the Shomrei Hachomos, an Orthodox chapel. They arrived to recognize a remarkable, resilient life and an act of courage that ended that life. (Moynihan 2007)

Mrs. Librescu, 72, called his act of heroism "very typical ... He was always, always helping, how[ever] he could. But he was not able to help himself." (Bulliet 2007)

In sum, The New York Post referenced only 11 of the victims in their 50 articles, whereas The New York Times referenced each victim at least once. Nevertheless, The Times had over three times the number of references to victims with 78 references, compared to just 23 in The Post. This is a contrast to the reporting of the shooter, which The Post focused on more heavily in their reporting of the event. The Post also ran more single-victim referenced articles than The Times, which chose to publish more victims in a single article as a grouping of biographical sketches. Notably, three of the victims who were referenced in articles had ties to the tri-state area - Matthew LaPorte was from New Jersey, Caitlin Hammaren from upstate New York, and Julia Pryde also from New Jersey.

\section{Discussion}

It is not entirely surprising that, given their sensational nature, cases like Virginia Tech receive so much media coverage. Murder typically receives the most attention of any type of crime news story (Chermak 1994, 1995; Maguire et al. 1999; Surette 1992), and some researchers have even found that stories of homicide can account for up to $40 \%$ of news coverage (Chermak 1995; Graber 1980; Pollak and Kubrin 2007). In order to capture and keep the audience's attention - the main goal Cerulo (1998) sees for news producers - the media may focus on cases that are high-amplitude (Johnstone et al. 1994) or those that specifically "deviate from what is statistically normal" (Chermak 1994: 580). As such, the abundance of news about crime, and more particularly homicide, can enable society to view violence as "normal" (Cerulo 1998).

The contributors to the production phase - editors, reporters and writers - must take a number of factors into consideration when deciding what to report on and how the material should be presented. If the goal is to hook an audience and keep them there (in hopes of increasing ratings and revenues), then the framing of news stories must play to audiences' interests (Cerulo 1998). However in doing this, newsmakers run the risk of disproportionately reporting an issue, which can have any number of effects on the news consumers. For instance, the amount of coverage for both the Columbine and Virginia Tech shootings provides viewers with an incorrect understanding of just how frequent these events are occurring. While on average school shootings occur less than 10 times per year (both preceding and postdating Columbine), the heightened media attention and sensationalization of selected cases makes the problem appear much more epidemic (Muschert 2007a; Muschert and Ragnedda 2010; Newman 2006; Sorensen, Manz, and Berk 1998).

The sequence through which the stories are reported can also impact the relationship between news producers and their consumers. Victim sequences, which appear to be the focus of The New York Times, may be more relatable 
to the reader (Cerulo 1998). By stressing the victims of the crime, newsmakers are at the same time emphasizing the wrongness of the crime (Bleyer 1932; Cerulo 1998). But is this enough to keep audiences hooked? Ratings would suggest otherwise. In fact, as an "infotainment society" (Kellner 2003: 11) built upon the notion of fast capitalism (Agger 1989), news consumers tend to gravitate more towards the performer sequences (Cerulo 1998). Audiences typically favor stories that are more graphic and violent (Chermak 1995; Gans 1979), and those committed by members of the out-group are often more heavily emphasized (Cerulo 1998), as was evident in the reportings in The New York Post.

There are a further number of implications both as a result of the shootings and the way in which the shootings are reported. Discourse after Virginia Tech called for a number of issues to be addressed. Among these were making schools safer, better emergency response procedures and stricter gun control legislation. In reality, school violence has been on the decline for quite some time (Best, 2006; Burns \& Crawford, 1999), yet a few "bad apples" overshadow such statistics. Virginia Tech police, like the SWAT teams responding to Columbine, were criticized for their response efforts. Many believe, and subsequently propagated through the media, that the Norris Hall shootings could have been prevented with a little better police work and more notification (King 2007/2008). As a response, college campuses nationwide immediately turned proactive in introducing new or refining existing emergency response plans that included multimodal communications to campus community members and more intense security measures (Luke 2007/2008). Gun control advocates and politicians battled back and forth about whether to repeal nationwide bans prohibiting firearms on campuses (Agger 2007/2008; King 2007/2008). Additionally, discourse spread like wildfire through the media about the legal loophole in Virginia's mental health laws that let Cho slip through the cracks - and legally purchase his weapons.

Cerulo (1998) posits that certain methods for storytelling can potentially reduce an audience's tolerance for violence. This can occur when news producers shift to performer sequence (Cerulo 1998), as that which occurred with the release of Cho's multimedia manifesto. Many news consumers actually objected to the airing of the video, citing that it gave Cho the platform he wanted to propagate his messages of death and destruction (Agger 2007/2008). The media can also use these stories to sway public opinion (Chermak 1994; Surette 1992), as occurred with Fox News' broadcasting Cho's narratives and subsequently introducing media-hired psychologists (who had never seen Cho's mental health records) to declare to millions of viewers that he was in fact insane (Agger 2007/2008). However, the over-reporting and desensitizing nature of prior stories like Columbine, even while increasing a level of fear of such heinous crimes, showed (in the ratings) that audiences just weren't buying.

A final contemplation for the framing of events, particularly from the sequence of the performer, is what message it sends to others who may be contemplating the same act. Columbine became an archetypal case of school violence because of its nature, and ultimately "pulling a Columbine" became a mantra of revenge for disgruntled and alienated youth (although as Ben Agger (2007/2008) so astutely notes, not all kids who are angry go out and "pump three bullets per victim"). However, Columbine also represents a break (or rather the introduction of an outside force) in the media cycle in respects to material control. While the media essentially had a field day once Cho's manifesto was received and aired by NBC, the counterpart documents for Columbine, The Basement Tapes, have never been released (Schildkraut, forthcoming). In this particular instance, it was the Jefferson County Sheriff's Office who made the call about what material was aired and what was not, rather than the decision being left up to news executives (Schildkraut, forthcoming). Is it then possible that the appeal of Columbine was such because of the unknown? Though the question is purely speculative, one also doesn't hear (at least not with the frequency and longevity of Columbine) that disgruntled students want to go out and "pull a Virginia Tech".

Though the news making process is a dynamic process with many moving parts, examining the components of production, content and consumption separately (as this study has done with the content) is important to provide a stronger foundation with which to understand media logic. In essence, it requires understanding the function of each part of a machine before you can understand how they all work together to make the machine function. Examining these components separately has also provided the opportunity to consider broader implications for the process as a whole. In understanding the content itself, it provides a better opportunity to create an open dialogue with the newsmakers of the production phase to understand their selection decisions and with consumers to understand why they do or do not consume certain stories.

Future research would benefit from comparing two national papers or two metropolitan papers for a more equitable comparison. Additionally, future research would benefit from comparing the findings in this study with reporting of other school shootings or mass disasters to determine if these news organizations use a similar 
methodology for presenting unique crime stories or if the Virginia Tech case is atypical. As a mediatized society, the news will continue to be a prime source of information for consumers, and understanding the reporting styles and decisions of producers, as well as the role of content, will be crucial in reducing any potential social panics that can result from tragic events such as the Virginia Tech Massacre.

\section{Endnotes}

1. The 1927 attack on a school in Bath, Michigan was in fact a deadlier event, claimed the lives of 45 people; however, the main weapon used was explosives and thus is not considered a "school shooting."

2. The total body count for the Columbine shooting is 15 , including the perpetrators who both committed suicide in the school's library.

3. For Monday through Friday paper circulations, The New York Times has a six-month circulation average of 1,150,589 and The New York Post has an average of 512,067 (Audit Bureau of Circulations, 2011).
4. According to Nielsen Online rankings, for the calendar year 2008, The New York Times had an average of 19,503,667 unique site visitors and The New York Post had an average of 4,335,583 unique site visitors (Seward, 2009).

5. In the Luby's Cafeteria event, George Jo Hennard drove his pick-up truck through the front window of the Killeen, TX eatery (Hayes 1991). As patrons rushed to his aid, Hennard opened fire, killing 22 patrons and wounding 20 others before turning the gun on himself.

\section{References}

Agger, Ben. 2007. "Cho, not Che?: Positioning Blacksburg in the political." Fast Capitalism, 3(1). Also reprinted in 2008 in Ben Agger \& Timothy W. Luke (Eds.), There is a gunman on campus: Tragedy and terror at Virginia Tech (p. 243-250). Lanham, MD: Rowman \& Littlefield Publishers, Inc.

Agger, Ben. 1989. Fast capitalism: A critical theory of significance. Chicago: University of Illinois Press.

Altheide, David. 1996. Qualitative media analysis. Newbury Park, CA: Sage.

Altheide, David. 2009. "The Columbine shootings and the discourse of fear." American Behavioral Scientist, 52: 1354-1370.

Audit Bureau of Circulations. 2011, September 30. Access ABC: eCirc for US newspapers. Retrieved from http://abcas3. accessabc.com/ecirc/newstitlesearchus.asp.

Belluck, Pam. 2007. "Intersecting on a fateful day, lives that spanned the country and the world: A candlelight vigil on the campus of Virginia Tech on Tuesday night." The New York Times, April 18. Retrieved from http://www.thenytimes.com.

Best, Joel. 2006. "The media exaggerate the school-shooting problem." In Susan C. Hunnicutt (Ed.), School Shootings (p. 18-27). Farmington Hills, MI: Greenhaven Press.
Birkland, Tom and Regina Lawrence. 2009. "Media framing and policy change after Columbine." American Behavioral Scientist, 52(10): 1405-1425.

Bishop, Ian. 2007. "Tough weapons still long shot: Pols." The New York Post, April 18. Retrieved from http://www.nypost. com.

Bleyer, Willard G. 1932. Newspaper writing and editing. Boston: Houghton Mifflin.

Broder, John M. 2007. "Massacre in Virginia: 32 shot dead in Virginia; Worst U.S. gun rampage." The New York Times, April 17. Retrieved from http://www.nytimes.com.

Buckler, Kevin and Lawrence Travis. 2005. "Assessing the newsworthiness of homicide events: An analysis of coverage in the Houston Chronicle." Journal of Criminal Justice and Popular Culture, 12(1): 1-25.

Bulliet, Mark. 2007. "Brooklyn cries for hero prof." The New York Post, April 19. Retrieved from http://www.nypost.com.

Burns, Ronald and Charles Crawford. 1999. "School shootings, the media, and public fear: Ingredients for a moral panic." Crime, Law, \& Social Change, 32: 147-168.

Celona, Larry, Sheehy, Kate, and C.J. Sullivan. 2007. "HS student prom-ises massacre." The New York Post, April 24. Retrieved from http://www.nypost.com. 
Cerulo, Karen. 1998. Deciphering violence: The cognitive structure of right and wrong. New York: Routledge.

Chermak, Steven. 1995. Victims in the news: Crime and the American news media. Boulder, CO: Westview Press.

Chermak, Steven. 1994. "Body count news: How crime is presented in the news media.” Justice Quarterly, 11: 561-582.

Chiricos, Ted, Padgett, Kathy, and Marc Gertz. 2000. "Fear, TV news, and the reality of crime." Criminology, 38(3): 755-785.

Chyi, Hsiang and Maxwell McCombs. 2004. "Media salience and the process of framing: Coverage of the Columbine school shootings." Journalism and Mass Communication Quarterly, 81:22-35.

Couldry, Nick. 2008. "Mediatization or mediation? Alternative understandings of the emergent space of digital storytelling." New Media Society, 10: 373-391.

Dewan, Shaila and Marc Santora. 2007. "Officials knew of troubled state of killer in '05." The New York Times, April 19. Retrieved from http://www.thenytimes.com.

Dowler, Kenneth. 2003. "Media consumption and public attitudes toward crime and justice: The relationship between fear of crime, punitive attitudes, and perceived police effectiveness." Journal of Criminal Justice and Popular Culture, 10(2): 109-126.

Downs, Anthony. 1972. "Up and down with ecology - the issueattention cycle." Public Interest, 28: 38-50.

Entman, Robert. 1993. "Framing: Toward clarification of a fractured paradigm." Journal of Communication, 43(4): 51-58.

Frymer, Benjamin. 2009. "The media spectacle of Columbine: Alienated youth as an object of fear." American Behavioral Scientist, 52: 1387-1404.

Gans, Herbert. 1979. Deciding what's news: A study of CBS Evening News, NBC Nightly News, Newsweek, and Time. New York: Vintage Books.

Garofoli, Joe. 2007. "Virginia Tech massacre: New-media culture challenges limits of journalism ethics." San Francisco Chronicle, April 20. Retrieved from http://articles.sfgate.com.

Gerbner, George, Gross, Larry, Morgan, Michael, and Nancy Signorelli. 1980. "The mainstreaming of America: Violence profile no. 11." Journal of Communications, 30: 10-29.

Goffman, Erving. 1974. Frame analysis: An essay on the organization of experience. Cambridge: Harvard University Press.

Graber, Doris A. 1980. Crime news and the public. Chicago, IL: University of Chicago Press.

Hayes, Thomas. 1991. "Gunman Kills 22 and Himself in Texas Cafeteria." The New York Times, October 17. Retrieved from http://www.nytimes.com.
Heath, Linda. 1984. "Impact of newspaper crime reports on fear of crime: Multimethodological investigation.” Journal of Personality and Social Psychology, 47: 263-276.

Hjarvard, Stig. 2008. "The mediatization of society: A theory of the media as agents of social and cultural change." Nordicom Review, 29(2): 105-134.

Johnstone, John W.C., Hawkins, Darnell F., and Arthur Michener. 1994. "Homicide reporting in Chicago dailies." Journalism Quarterly, 71(4): 860-872.

Kellner, Douglas. 2003. Media Spectacle. New York: Routledge.

King, Neal. 2007. "Mediated ritual on academic ground." Fast Capitalism, 3(1). Also reprinted in 2008 in Ben Agger \& Timothy W. Luke (Eds.), There is a gunman on campus: Tragedy and terror at Virginia Tech (p. 55-64). Lanham, MD: Rowman \& Littlefield Publishers, Inc.

Kleinfield, N.R. 2007. "Before a deadly rampage, a life consumed by troubling silence." The New York Times, April 22. Retrieved from http://www.nytimes.com.

Liska, Allen E. and William Baccaglini. 1990. "Feeling safe by comparison: Crime in the newspapers." Social Problems, 37: 360-374.

Lowry, Rich. 2007. "Campus massacre: We let loose the loonies." The New York Post, April 20. Retrieved from http:// www.nypost.com.

Luke, Timothy W. 2007. "April 16, 2007 - To: Multiple recipients: 'There is a gunman on campus'” Fast Capitalism, 3(1). Also reprinted in 2008 in Ben Agger \& Timothy W. Luke (Eds.), There is a gunman on campus: Tragedy and terror at Virginia Tech (p. 1-28). Lanham, MD: Rowman \& Littlefield Publishers, Inc.

Luke, Timothy W. 1989. Screens of Power: Ideology, Domination, and Resistance in Informational Society. Chicago: University of Illinois Press.

Lundman, Richard J. 2003. "The newsworthiness and selection bias in news about murder: Comparative and relative effects of novelty and race and gender typifications on newspaper coverage of homicide." Sociological Forum, 18(3): 357-386.

Maguire, Brendan, Sandage, Diane, \& Georgie Ann Weatherby. 1999. "Crime stories as television news: A content analysis of national big city and small town newscasts." Journal of Criminal Justice and Popular Culture, 7: 1-14.

McCombs, Maxwell and Jian-Hua Zhu. 1995. "Capacity, diversity, and volatility of the public agenda: Trends from 1954 to 1994." Public Opinion Quarterly, 59(4): 495-525.

Meyers, Marian. 1997. News coverage of violence against women: Engendering blame. Thousand Oaks, CA: SAGE.

Muschert, Glenn. 2009. "Frame-changing in the media coverage of a school shooting: The rise of Columbine as a national concern." Social Science Journal, 46(1): 164-170.

Muschert, Glenn. 2007a. "Research in school shootings." Sociology Compass, 1(1): 60-80. 
Muschert, Glenn. 2007b. "The Columbine victims and the myth of the juvenile superpredator." Youth Violence and Juvenile Justice, 5(4): 351-366.

Muschert, Glenn. 2002. "Media and massacre: The social construction of the Columbine story." Doctoral dissertation: University of Colorado at Boulder.

Muschert, Glenn and Dawn Carr. 2006. "Media salience and frame changing across events: Coverage of nine school shootings, 1997-2001." Journalism \& Mass Communication Quarterly, 83(4): 747-766.

Muschert, Glenn and Ralph Larkin. 2007. "The Columbine High School shootings.” In Steven Chermak \& F.Y. Bailey (Eds.), Crimes and trials of the century (p. 253-266). Westport, CT: Praeger.

Muschert, Glenn W. and Massimo Ragnedda. 2010. "Media and Violence Control: The Framing of School Shootings." In Wilhelm Heitmeyer, Heinz-Gerhard Haupt, Stefan Malthaner, and Andrea Kirschner (Eds.), The Control of Violence in Modern Society: Multidisciplinary Perspectives, From School Shootings to Ethnic Violence (p. 345-361). New York: Springer Publishing.

Newman, Katherine. 2006. "School shootings are a serious problem.” In Susan C. Hunnicutt (Ed.), School Shootings (p. 10-17). Farmington Hills, MI: Greenhaven Press.

Newman, Katherine, Fox, Cybelle, Harding, David, Mehta, Jal, and Wendy Roth. 1994. Rampage: The social roots of school shootings. New York: Basic Books.

Pew Research Center for the People and the Press. 2007, April 25. "Widespread interest in Virginia Tech shootings, but public paid closer attention to columbine." Retrieved from http://people-press.org/report/322/ widespread-interest-in-virginia-tech-shootings.

Peyser, Andrea, de Kretser, Leela, and David K. Li. 2007. "Stalker who turned killer: Students knew he was a time bomb." The New York Post, April 18. Retrieved from http://www.nypost. com.

Pollak, Jessica M. and Charles E. Kubrin. 2007. "Crime in the news: How crimes, offenders and victims are portrayed in the media." Journal of Criminal Justice and Popular Culture,14: 59-83.

Pritchard, David and Karen D. Hughes. 1997. "Patterns of deviance in crime news." Journal of Communication, 47(3): 49-67.

Reese, Stephen. 2007. "The framing project: A bridging model for media research revisited.” Journal of Communication, 57: 148-154.

Scheufele, Dietram. 1999. "Framing as a theory of media effects." Journal of Communication, 49(1): 103-122.

Scheufele, Dietram and Richard Tewksbury. 2007. "Framing, agenda setting, and priming: The evolution of three media effects models." Journal of Communication, 57: 9-20.
Schildkraut, Jaclyn. 2012. "The Remote Is Controlled by the Monster: Issues of mediatized violence and school shootings." In Glenn Muschert \& Johanna Sumiala (Eds.), School shootings: Mediatized violence in a global age (pp 235-258). Bingley, UK: Emerald Group Publishing Limited.

Schildkraut, Jaclyn and Amy M. Donley. 2012. "Murder in black: A media distortion analysis of homicides in Baltimore in 2010.” Homicide Studies, 16(2): 175-196.

Seward, Zachary M. (2009, February 17). Top 15 newspapers of 2008. Retrieved from http://www.niemanlab.org/2009/02/ top-15-newspaper-sites-of-2008.

Sheehy, Kate. 2007. "Nightmare at Virginia Tech is worst shooting slaughter in U.S. history." The New York Post, April 17. Retrieved from http://www.nypost.com.

Shoemaker, Pamela and Stephen Reese. 1996. Mediating the message: Theories of influence on mass media content (2nd ed). White Plains: Longman Publishers USA.

Sorensen, Susan B., Manz, Julie G. and Richard A. Berk. 1998. "News media coverage and the epidemiology of homicide." American Journal of Public Health, 88: 1510-1514.

Spencer, J. William. 2005. "It's not as simple as it seems: Ambiguous culpability and ambivalent affect in news representations of violent youth." Symbolic Interaction, 28(1): $47-65$.

Strauss, Anselm and Juliet Corbin. 1998. Basics of qualitative research: Techniques and procedures for developing grounded theory (2nd ed.). California: SAGE Publications, Inc.

Surette, Ray. 1992. Media, crime, and criminal justice: Images and realities. Belmont, CA: Wadsworth, Inc.

Tankard, James W. 2001. "The empirical approach to the study of media framing.” In Stephen D. Reese, Oscar H. Gandy, Jr., \& August.E. Grant (Eds.), Framing public life: Perspectives on media and our understanding of the social world (p. 95-106). Mahwah, NJ: Lawrence Erlbaum.

United States Federal Bureau of Investigation. 2003. Columbine High School. Washington, D.C.: Federal Bureau of Investigation. Retrieved from http://purl.access.gpo.gov/ GPO/LPS97619.

Urbina, Ian and Manny Fernandez. 2007. "Memorial services held in U.S. and around world." The New York Times, April 17. Retrieved from http://www.nytimes.com.

Urbina, Ian and Suevon Lee. 2007. "For schools, several ties to shootings." The New York Times, April 18. Retrieved from http://www.nytimes.com.

Virginia Tech Review Panel. 2007. Mass Shootings at Virginia Tech April 16, 2007: Report of the Review Panel. Arlington: Governor's Office of the Commonwealth of

Winter, Jana, Li, David K., and Hasani Gittens. 2007. "Mad killer's TV hate mail: Sent chilling package between shoot sprees." The New York Post, April 19. Retrieved from http:// www.nypost.com. 